\title{
Property Rights, Institutions and Forest Resources Management in Developing Countries
}

\author{
Djiby Racine Thiam \\ Center for Development Research (ZEF), Walter-Flex-Strasse 3, University of Bonn, Bonn, Germany \\ Email: dthiam@uni-bonn.de
}

Received 10 December 2013; revised 6 February 2014; accepted 19 February 2014

Copyright (C) 2014 by author and Scientific Research Publishing Inc.

This work is licensed under the Creative Commons Attribution International License (CC BY).

http://creativecommons.org/licenses/by/4.0/

(c) (i) Open Access

\begin{abstract}
The objective of this paper is to propose a conceptual framework stimulating the sustainable management of natural resources in Central Africa. Based on the forest resources, we show how good identification and allocation of property rights strengthen the joint management of forest resources. Cameroon is selected as an example, since the country represents one of the most forest-intense areas in Africa. In doing so, we first evaluate the performance of institutions in fostering sustainable forest management. Second we show how good elaboration and allocation of property rights may contribute to improving efficiency in forest management. Using the New Institutional Economic (NIE) theory we provide an outline of the potential relationships between forest management and property rights allocated to stakeholders involved in forest exploitation. Finally we provide two forms of institutional structures that could improve forest management efficiency: public-private partnership and multi-stakeholder management approaches. Public-private partnerships are joint project management processes operated by both private businesses and public entities in order to combine public prescriptive mechanisms with private operational roles. Multi-stakeholder management approach is also a co-management initiative combining public entities, private actors and local population to increase the involvement of local dwellers living in forest areas in the decision process.
\end{abstract}

\section{Keywords}

Natural Resources; Forest; Cameroon; New Institutional Economics; Property Rights; Joint Forest Management 


\section{Introduction}

Forest represents one of the major components of natural resources as it combines physical, economic and social characteristics. In the African context forests contribute to the improvement of households' livelihoods [1]-[6]. For example when rightly exploited the resource provides incomes to many rural households, through a sale of fuel-wood collected. In a macroeconomic picture the use of the resource provides 1) tax incomes to the government 2) captures the carbon emissions and 3 ) alleviates poverty ${ }^{1}$ in creating jobs. Beyond these economic advantages, forests ensure to the continent environmental and social advantages. Their sustainable management promotes the conservation of biodiversity, reduces deforestation, mitigates and adapts the consequences of climate change and absorbs atmospheric carbon [3] [7] [8]. Forests are also strongly linked to food security especially in rural areas of developing countries ${ }^{2}$. For instance in rural areas of the Congo Basin, five to six million tonnes of bush meat are harvested each year and account for up to 80 percent of the fats and proteins consumed by local communities.

Due to these important roles played by the resource in an economy, the objective of this paper is to investigate the roles of local institutions in fostering forest management in Cameroon. Indeed understanding the dynamics and the nature of institutions is very important for an improvement of natural resource management [1] [9] [10]. Cameroon is selected as a case study because the country represents one of the most forest-abundant regions in the continent. Cameroon forest area, including in the Congo Basin, ranges from 155,000 square kilometers-33\% of national territory to 206,000 square kilometers-44\% of national territory [11]. Moreover, in 2005, tax incomes collected from the sector amounted to $79 \mathrm{M} \mathrm{US} / \$$ (MINFOF, 2008). Finally the sector provides between 45,000 and 70,000 jobs and accounts to more than $10 \%$ of the country's GDP [12].

In order to provide an institutional framework strengthening forest resources management in Cameroon, this paper follows two steps. First, we examine the existing institutional structures ${ }^{3}$ of the forest sector within the country and assess their efficiency and accountability since the introduction of the 1994 forest legislation ${ }^{4}$. Institutional efficiency is assessed through 1) the capacity of institutions to protect the forest against degradation ${ }^{5}$ (purpose function) and 2) their internal mechanisms of functioning (operational function). Such an assessment could therefore allow an identification of the strengths and limits of the existing institutions. Second, we use the theory of New Institutional Economics (NIE) ${ }^{6}$ and show how good identification and allocation of property rights improve management of forest resources. NIE analyzes the relations between institutions and stakeholders in investigating how existing routines (social organizations) and policies within societies might drive the management of natural resources [15] [16]. Finally the paper discusses the impacts of two forms of institutional arrangements on forest management: Public Private Partnership (PPP) and Multi-Stakeholder (MLS) management approaches. Public-Private Partnerships are joint project management processes operated by private businesses and public entities in order to combine public prescriptive mechanisms with private operational roles. Multi-Stakeholder management is also a co-management approach combining public entities, private actors and local population in order to increase the contribution of local dwellers living in forest areas in the decision making process. These two forms of institutional frameworks are considered as joint forest management (JFM) because they promote cooperation between different stakeholders during the management of forest resources [17].

The paper is organized as follows. Section 2 presents the current institutional structures in charge of forest management in Cameroon. Section 3 assesses the efficiency and accountability of the institutional structures. Using the NIE theory, Section 4 discusses how forest resources could be jointly managed through an identification and allocation of property rights. Section 5 proposes two forms of institutional arrangements to promote JFM: public-private partnership and multi-level stakeholder management approaches. Conclusion is provided in

\footnotetext{
${ }^{1}$ For example [13] provides linkages between different African National Forest Programs and poverty alleviation.

${ }^{2}$ See [14] Forests for improved nutrition and food security, Policy brief.

${ }^{3}$ There is a difference between institutional framework and structure. We assume by institutional structure the set of past, current and future structures established for a sustainable management of forest resources. Institutional framework captures the set of laws, regulations, procedures and customs that guide sustainable management of forest resources.

${ }^{4}$ The scopes and details of the law are explained later in this paper. Efficiency and accountability are assessed after the introduction of the forest policy (i.e. 1994).

${ }^{5}$ In this paper, forest degradation refers to deforestation. We acknowledge that this definition can be limited because forest degradation goes beyond deforestation and embeds any negative changes affecting forest (overexploitation, fires, firewood scavenging, animal foraging etc.). [2] defines forest degradation as a reduction in capacity of a forest or canopy cover and stocking to provide goods and services. We adopt this simplistic definition to be able to use data collected in assessing efficiency of institutions.

${ }^{6}$ The purpose of the NIE is both to explain the determinants of institutions and their evolution over time, and to evaluate their impact on economic performance, efficiency, and distribution [19].
} 
the last section, Section 6 .

\section{Institutions and Forest Resources in Cameroon}

Before presenting the institutional structures used to manage forest resources, it is important to present the regulatory framework elaborated by the government of Cameroon in order to promote sustainable management of forest resources. Historically, two major laws have been passed: the laws No 94/01 and No 96/12 [18]. The law No 94/01 of 20 January 1994 provided a legislative framework monitoring management and exploitation of forest resources. The law assumes that forest protection remains a state responsibility. The law classified the forests into two categories: permanent (protected forest) and non-permanent forests. Permanent forests include both national and municipal forests whereas non-permanent forests include forests of the national domain, community-based forests and privately owned individual forests. Forests of national domain aim at protecting the regeneration of trees, since the areas allocated as national domains cannot be used for other productive activities such as agriculture, fallows and pastoral. Community-based forests incorporate local dwellers in the management of forest resources. With community-based forests, local population receives technical support from the state. The privately owned individual forests as their names indicate belong to private properties. The second legislation regulating forest management is the law No 96/12 of 5 August 1996, that provided a legal framework for monitoring and a management of the environment. That law introduced an objective of environmental protection during timber exploitations. The aim was to promote the sustainable management of natural resources to protect biodiversity. The law introduces the "principle of responsibility" in which environmental protection should be the responsibility of all stakeholders (populations, public authorities, logging companies, NGOs and civil society). Figure 1 shows the typologies of forests in Cameroon.

The institutional structure of the forest sector in Cameroon has taken various forms over the past two decades. In 1992, after the Rio Conference, the Government created the "Ministére de la Forêt et de la Faune 7(MINFOF)". Within MINFOF the departments of forest, fauna and protected areas and the promotion and transformation of forest products are the main departments responsible for the design of strategic policies promoting a sustainable management of forest resources.

Beyond MINFOF, the "Office National de Développement des Forêts (ONADEF)" plays an important role within the structure. The mandate of ONADEF is to provide quantitative assessment of forest resources. Cameroon also played an important role in the creation of the "Commission des Forêts d'Afrique Centrale (COMIFAC)". Indeed in 1999 the country hosted the "Yaounde Forest Summit" where the Governments of the Central African countries met to discuss strategies and options that should be mobilized at regional level to facilitate sustainable forest management. The major institutional architecture that came out from the summit was

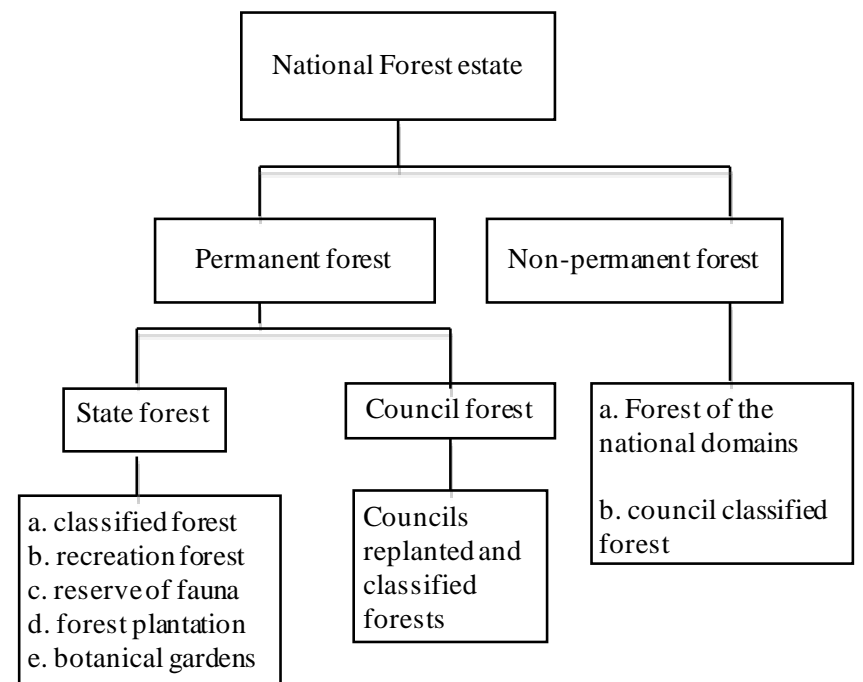

Figure 1. Typologies of forests in Cameroon, adapted from [20].

${ }^{7}$ Ministry of Forestry and Wildlife (MINFOF). 
COMIFAC, an institution with an objective to providing expertise and advice to the different Central African countries. Moreover, [21] argues that forest planning in Cameroon follows three major plans: the National Forest Action Plan (NFAP), the National Plan of Management of the Environment (NPME) and the Emergency Action Plan (EAP). The National Forest Action Plan (NFAP) aims at strengthening national and local institutions in their role to facilitating policy implementation in the sector. The National Plan of Management of the Environment (NPME) promotes and supports involvement of local community-based stakeholders (households, civil society, small-scale farmers, etc.) in environmental protection. Because it is widely acknowledged that an involvement of local stakeholders facilitates the overcoming of cultural barriers and therefore contributes to a better acceptance of government programs and policies within local indigenous groups [18]. Finally the Emergency Action Plan (EAP) aims at providing urgent measures that protect against forest degradation.

\section{Assessing Institutional Performance in Managing Forest Resources}

Two criteria are used in assessing institutional performance in forest management: the capacity of institutions to reduce forest degradation (objective function) and the internal mechanisms of functioning of institutions (operational function). As mentioned earlier, in this paper forest degradation refers to deforestation. Table 1 shows the evolution of deforestation and wood exploited with regard to the implementation of the forest laws ${ }^{8}$. It shows an increase of deforestation and wood collected over the past years, though forest law had been passed in 1994 with an objective to reducing deforestation and promoting a more sustainable use of wood resources. On average the annual deforestation rate between 1990 and 2010 amounts to $0.9 \%$. Due to lack of long-term time series data we could not compute the evolution of deforestation since 1960. However [22] find a deforestation rate of $0.8 \%$ between 1973 and 1988. That means forest policy introduced by the government did not really reduce forest degradation in the country. Such a situation questions the efficiency of institutions since their main objective was to prevent forest degradation.

The second criterion used to evaluate efficiency of institutions is the internal mechanisms of functioning of the current institutions (operational form). In the country one must first distinguish between state versus management-based and national versus regional-based institutions. The state-based institutions (MINFOF, ONADEF) are all existing state entities created for a smooth functioning of forest management whereas management-based institutions (NFAP, NPME, EAP) refer to selective plans scheduled by policy-makers to implement policy measures in the sector. Finally regional-based institutions (COMIFAC) are those built to promote cooperation between the Central African countries. Assessing the efficiency of institutional structures requires, first, an identification of their responsibilities and means of action [24] [25]. In Cameroon, the responsibilities of the state-based institutions are 1) to design and provide a follow-up in implementation of forest policy; 2) to ensure the control of actors involved in the sector and 3) to provide financial and technical assistance to the different parties involved in forest management [18]. The responsibilities of management-based institutions are to

Table 1. Law enforcement and forest degradation.

\begin{tabular}{ccccc}
\hline & & Forest (ha) & Deforestation (ha) & Wood exploited (3 m) \\
\hline Year & Activities & & & \\
1998 & Preparation forest law & & & 2.5 \\
1990 & Establishment of forest law & 23.436 & 880 & 2.7 \\
1994 & $\begin{array}{c}\text { Law monitoring management of } \\
\text { natural resources } \\
1995\end{array}$ & 23.216 & 220 & 3.4 \\
1998 & $\begin{array}{c}\text { Defining auction } \\
\text { criteria/revisiting the allocation } \\
\text { mechanisms of concession rights }\end{array}$ & 22.556 & 660 & 1624 \\
\hline
\end{tabular}

Source: Adapted from [23]; Data is collected from published literature and Government reports (in $10^{3}$ ).

${ }^{8}$ However it is important to highlight that, beyond forest law, there are other factors (economic growth, increase of population, individual preferences, etc.) which could also affect forest degradation. 
facilitate implementation of designed policies and the regional-based institutions provide advise to the Central African governments on sustainable management principles. Therefore the efficiency of forest institutions in Cameroon remains uncertain. Although the current institutions have allowed the country to produce a coherent and consistent forest policy in 1994, they however failed to facilitate its implementation. The failure to implement such a policy is due to a combination of factors such as: lack of transparency and accountability of public servants and an inconsistent synchronization of the interests of the different stakeholders ${ }^{9}$. Failure to implement such policies is also due to the weak involvement of community-based populations in the decision-making process [26] [27]. Indeed the structure and nature of the power relationships between different parties involved in forest management play a very important role in enlightening the constraints of policy implementation in the sector [28]. Although the regulatory framework provided in the country targeted a better involvement of local dwellers in the decision process, one can remark that many problems still arose between government entities and social actors. For instance when interviewing people in Cameroon, [29] found out that the local communities were irritated by the behavior of the government because they said that the state does not want to share with them the benefits of forest resources, since it "takes back with the left hand what it gives with the right hand". Though the government tried to create a platform involving members of the village committees, municipal authorities, administrative officials and timber companies, local populations perceive this as an inefficient way to bring their voices in the decision process. Moreover local dwellers argue that such a platform is made up to keep forest royalties at the regional level in order to share them or to mismanage them [29].

The impact of the forest legislation has been negligible so far due to the lack of controls and the non-respect of the law ${ }^{10}$. The failure of control reflects the fact that the state entities are not fully able to monitor the logging activities, leading therefore to an increase in illegal activities. [12] argues that, in the country, the most common illegal activities in the sector are: harvesting outside concession boundaries, harvesting without title, disrespect of management plans with regards to both geographical scope and technical aspects, unlawful transportation of wood and false declaration of timber volume. Analyzing the causes of illegal activities, [30] finds systemic corruption, poverty, conflicts, licensing schemes, usurpation of property rights and inadequate institutional support as the main causes of illegal activities. Furthermore it is estimated that the government is losing between 5 and 10 million USD/year in revenue from the felling tax alone due to illegal activities [31]. Controlling these illegal activities are however difficult, since the current institutions in charge of such control are tremendously influenced by political power [32]. For instance, [21] argues that the lack of control explains $90 \%$ of the negative outcome of forest management in the country. In investigating the different factors that could explain the weakness of control in the sector [12] identifies poor implementation capacity of governmental officials and their lack of transparency in dealing with the illegal activities, the possibility of logging companies to negotiate with the government, the lack of accountability of the public servants leading to corruption and the difficulty of the state to monitor and compile the information provided by logging companies as the main causes of the weakness of control. Therefore, we argue that to improve the control of forest exploitation, collaboration should be promoted between public authorities, logging companies, households, civil society and resource users. For example control could be improved by raising awareness among the population about the economic and environmental consequences of such illegal activities and/or by establishing independent observer groups—such as local witnesses - among the communities to inform public authorities when such activities occur. In the past controls took technical forms such as the use of satellite photos and Geographical Information System (GIS) [33]. The "Unité Centrale de Contrôle" assisted by independent observer - global witness—and regulated concessionaires had also been created to enforce controls on logging [32]. Their outcomes are mitigated due to lack of transparency since the details and processing stages of their findings are not readily accessible [32].

Therefore the failure of the current institutions to protect forests against degradation requires an establishment of new strategies that facilitate a smooth management of natural resources. This paper argues that a better respect of allocated property rights and an innovative joint-management initiative combining government, private actors and local population (PPP and multi-stakeholder management practices) might provide a consistent alternative in promoting sustainable forest management. In doing so we use the theory of new institutional economics (NIE) to elucidate the existing relationships between property rights and forest management and an improvement of institutional efficiency.

\footnotetext{
${ }^{9}$ Information collected during a face-to-face interview with some rural populations in Dja in 2012.

${ }^{10}$ According to a manager working in one of the most important timber exploitation company in the region.
} 


\section{New Institutional Economics and Natural Resource Management}

The contribution of NIE on natural resource management in Cameroon could be articulated around a set of property rights allowing a paradigm shift embedding public and private actors and resource users. The theory of new institutional economics (NIE) overcomes the paradox left by the neo-classical economics by first, assuming the bounded rationality among economic agents and second, the imperfect information. One of the main objectives of (NIE) is to include the heterogeneity of agents within the decision choice. Included in natural resources economics, NIE provides a better understanding of the conditions that promote institutional efficiency ${ }^{11}$ in forest management [34], in investigating how different actors might cooperate to achieve a certain objective [35]-[39], while considering the characteristics and voices of local populations during a decision making process. Different authors have argued that a sustainable management of forest resources requires a good identification and allocation of property rights [40] [41]. [42] argues that property rights are designed to reduce open access to forest land and to establish competitive markets in timber exploitation. The allocation of property rights is performed using state, private and collaborative approaches [42]. In Cameroon until recently one of the most used property rights allocation forms was the state approach through a creation of permanent forest areas based on the 1994 law [43]. From the governance perspective, property rights are managed either through privatization or decentralization [44]. Under state management, rights of forest exploitation and management and all associated transaction costs are directly supported by the state whereas in a private management private operators support such costs. During collaborative management, different types of partnerships could eventually be agreed upon to share the costs, risks and benefits associated with forest management. When the private sector exploits and manages forest resources, the allocation of licenses becomes a real challenge, since the public regulator should ensure the trade-off between natural resource exploitation and sustainability of resources. For example [45] argues that involving private actors into the management of natural resources is a practical way to overcome constraints imposed by the "tragedy of the commons", because private property combines both exclusivity and transferability [46]. In the case of forest management, one can for example imagine the public-private partnership and multi-stakeholder structures, where the state and the private actors collaborate jointly to manage forest resources. Figure 2 shows the link between property rights and NIE.

\section{Property Rights and Forest Management}

In Cameroon the transfer of property rights from public to private actors or forest users is more or less identical to many Sub Saharan African countries [48]. In many African countries forests follow statutory laws in which the resource remains a state's property. For example the state allocates forest areas to local communities instead of allocating the land, preventing any customary laws. Most of the land is classified as national land, including farmland and communal land held under customary law [49]. The Government can convert national land into state land and allocate use rights or convert it to private ownership. [50] argues that such a system entails uncertainty about long-term tenure security and provides few incentives for undertaking land investments and improvements.

Consequently designing optimal allocation of property right in Cameroon is very helpful for a sustainable management of forest resources. To provide good-structured property right regimes, policy-makers might for instance adapt the conceptual framework developed by [51] to the socio-economic characteristics of the country while taking into account the economic role of the forest resources on the national economy. [51] identified five different right regimes that are used to manage natural resources: the right to access the resource, to withdraw the resource, to manage the resource, to exclude others from the use of the resource and to alienate part or all feasible uses to third parties. [52] argues that such a nomenclature allows for the differentiation between an operational and a collective-choice level rights. Moreover in the Cameroonian context, defining both access and withdrawal rights are done following a top-down governmental principles, since these two rights (access and withdrawal) are managed from the Ministry of the Environment and the Forest. Generally these rights are given to logging companies, without integrating indigenous populations, which for instance prevents the sustainability of the operational-level rights. The management, exclusion and alienation rights are carried out by the state through the use of networks provided by logging companies. The exploitation rights are only granted to the

\footnotetext{
${ }^{11}$ We understand by “institutional efficiency” the definition provided in [25]. The authors assume that institutional efficiency reflects a situation in which there is no feasible alternative for the state to create and enforce property and contract rights that everyone finds at least as good and which at least one of the economic actors strictly prefers.
} 


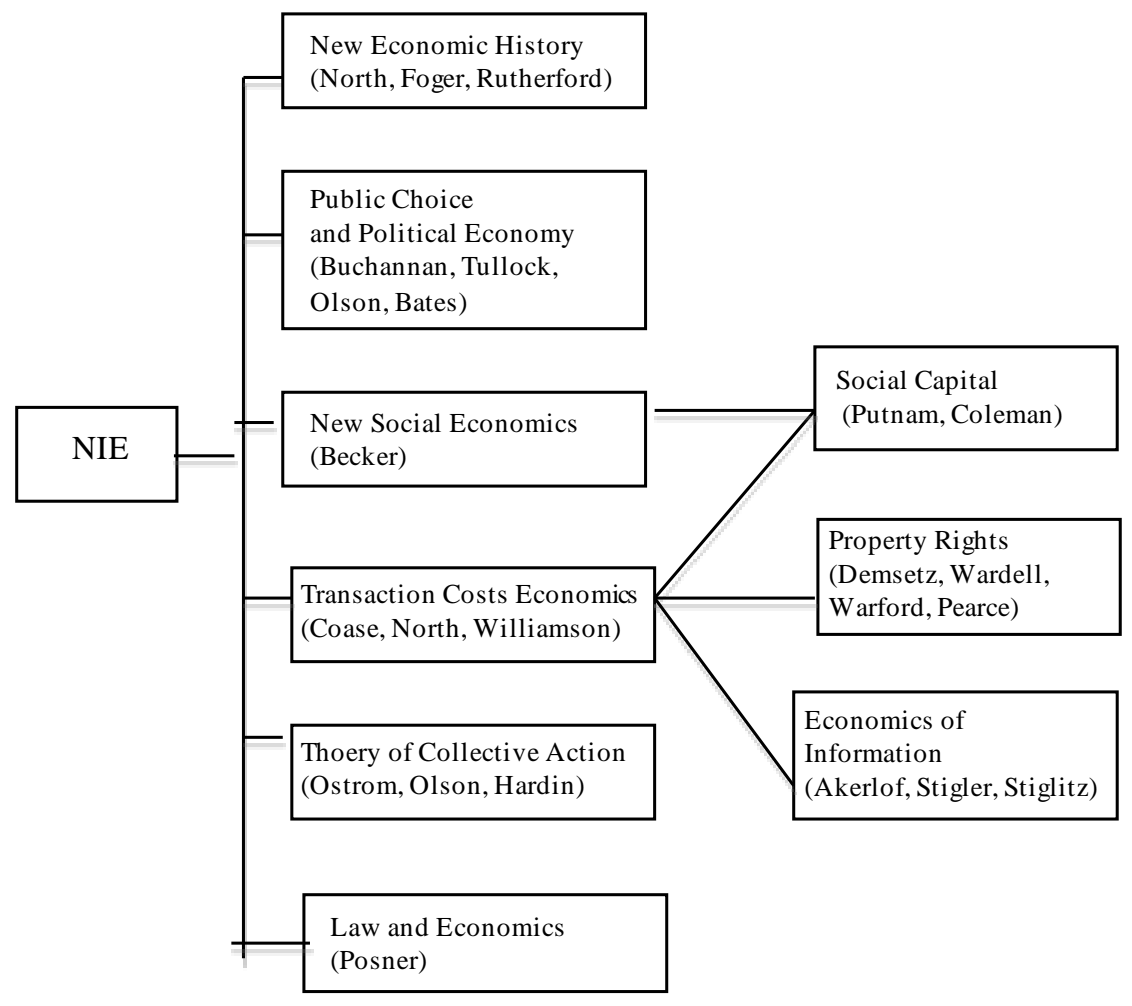

Figure 2. Branches of the New Institutional Economics; Source: [47].

residents or to companies with offices registered in Cameroon and shareholders known to the forestry services [20]. Moreover, the country has four different forms of exploitation rights [20]: exploitation contract (EC), sales of standing volume (SV), permit (PE) and individual felling authorization (IF). They confer to their holders the rights above mentioned provided in [51]. In the case of exploitation contractlicenses are delivered by the Ministry of the Environment and Forest to some logging companies, to allow them to collect specific quantities of wood from forest concessions. The SV and PE are quantity-based mechanisms used to fix a percentage of forest to logging companies, either not exceeding 2500 ha for the SV or 500 gross cubic meters for PE [20]. Finally IF gives to households rights to use forest wood less than 30 gross cubic meters.

Beyond a clear identification and allocation of property rights, managing forest resources in Cameroon requires clear strategies that combine state, private and local actors (Figure 3). The first step is to design and allocate property rights and furthermore, a legal framework is provided to investors and local communities to optimally manage forest resources. In providing both a platform where property rights are designed and their allocation schemes monitored and a legislative framework where logging companies could appropriately make business, thus the state has entirely played its prescriptive role. Then the responsibilities of private actors and logging companies are to invest in timber exploitation while respecting the criteria fixed by the Government, financial institutions and NGOs. Moreover a well-defined property right regime requires also a clear identification of stakeholders, their strengths, interests and means of actions.

\section{Institutional Structures for Joint Forest Management}

We propose two forms of institutional structures: public-private partnership and multi-stakeholder management approaches. Both are different forms of joint forest management, as noticed in [17], because they combine state prerogatives with private and local responsibilities.

\subsection{Public-Private Partnership in Forest Management}

Public-private partnerships are joint project management processes operated by private businesses and public entities. PPP provides a new form of institutional arrangement to manage forests in Cameroon, because 


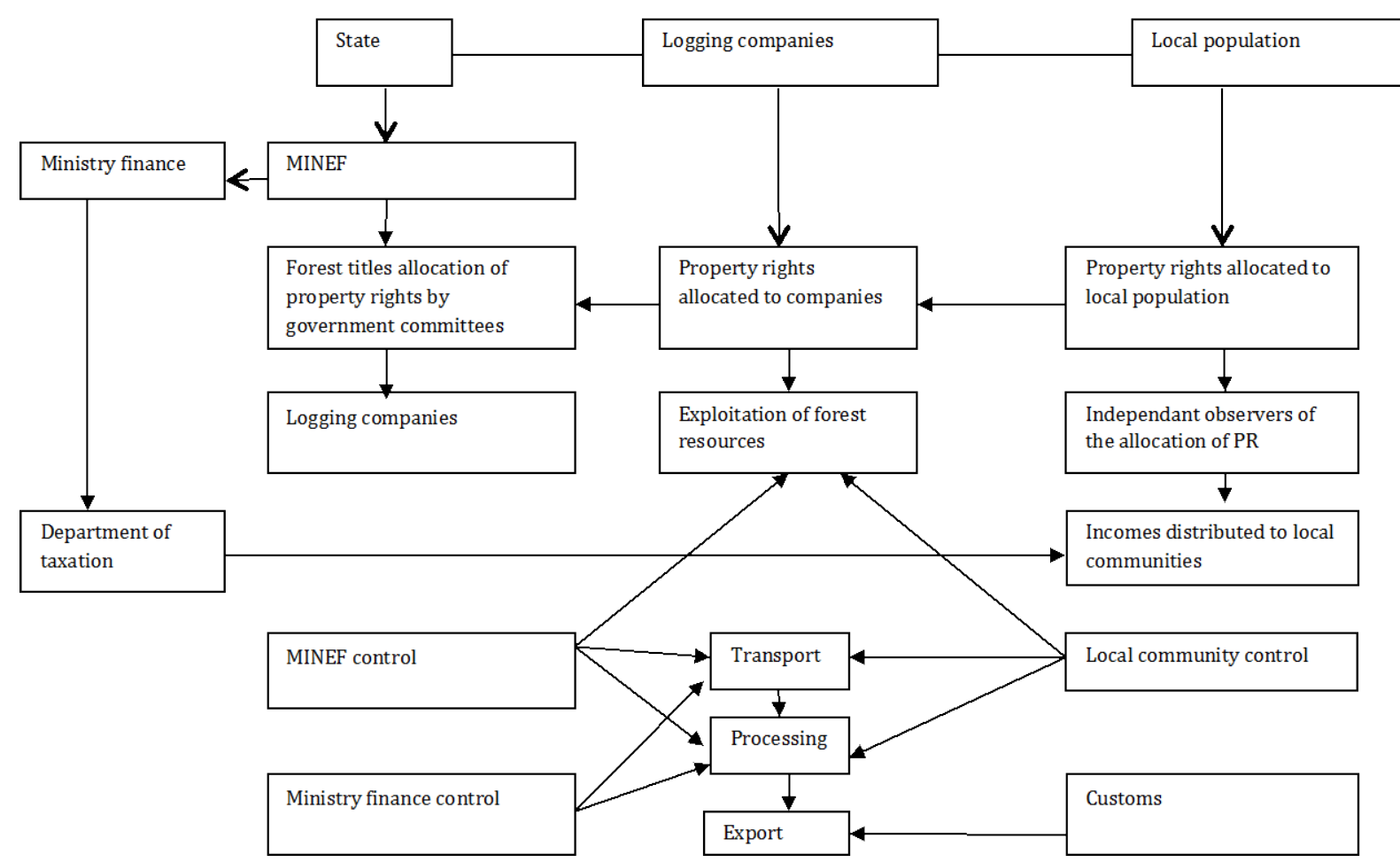

Figure 3. Framework for the design and allocation of property rights in the forest sector.

including private actors in the management of forest resources allows the government to diversify its financial resources and to benefit from high private skills and expertise. For example a PPP was built between the German development agency (GTZ) and "Société d'exploitation forestiére et agricole du Cameroun" (SEFAC) to improve forest certification in some concessions. That partnership was scheduled for one year running from February 2006 to May 2007. SEFAC detains five forest concessions accounting 405.000 ha in the south east of the country. The outcomes of such a PPP have allowed the provision of 1) an operational and efficient traceability system, 2) a training of personnel involved in data collection and 3) an internal follow-up plan (elaborated every quarter).

Moreover different private companies are operating in the forest sector in Cameroon. Table 2 shows the current companies operating in the forest sector in Cameroon, their origins, production and processing units. Although foreign entrepreneurs are less represented than the domestic ones, they produce and process more timber.

For example, with PPP the state can only have a prescriptive role, in introducing control mechanisms that guarantee the respect of allocated logging titles. Four different logging titles exist in the country [53]: 1) exploitation permits 2) individual felling authorization 3) sole of standing volume, and 4) forest management unit. In selecting private partners to allocate concession rights, the state should ensure a good monitoring of the economic rent that is captured by logging companies. The state also verifies if the forest exploitation guidance draft is followed. In reality, evidence has shown the difficulties in capturing rent [54], since logging companies are not strictly controlled due to the reasons given above. In the literature, rent is captured through instruments such as forest fees, royalties on stumpage, felled timber and round wood entering mills and export taxes. In the African continent, [54] [55] acknowledge the difficulty of introducing area tax as an instrument of rent capture due to the difficulties of finding a fair and encouraging tax system.

Building PPP for the management of forest resources should also take into account some characteristics such as forest resource heterogeneity among the different provinces, the structure of the logging market and the technical and financial capacities of private partners. A good knowledge of forest resource heterogeneity allows a better assessment of tax design. Hence forest inventory is necessary to capture forest endowment within the country. The structure of the logging market is also important to be considered because it impacts on the dynamics of the partnership between public and private actors. For example, a market-oriented scheme will facilitate the control over the rent because it solves the problem of information asymmetry, especially if the allocation 
Table 2. Logging companies ownership and timber processing units.

\begin{tabular}{cccc}
\hline Nationality entrepreneurs & Number of entrepreneurs & Total log production $\left(\mathrm{m}^{3} / \mathrm{year}\right)$ & Timber processing $\left(\mathrm{m}^{3}\right)$ \\
\hline Domestic & 78 & 997.352 & 55000 \\
Foreign & 28 & 1724.091 & 178000 \\
Joint venture & 7 & 30.802 & 86400 \\
Total & 113 & 2752.845 & 319400 \\
\hline
\end{tabular}

Source: Foahom (2001).

of concession rights is undertaken through a bidding process. Finally, selecting a private partner should also be carried out whilst considering the internal financial, technical and managerial capacities of the logging companies. Considering these factors facilitates the diversification of financial resources and the risk sharing among the different partners and strengthens the capacity building for local people working in logging companies.

In Cameroon building a PPP scheme can eventually follow three steps. First, the investigation phase clearly identifies potential private partners. Once such partners are identified the state assesses the impacts of such partnerships on the livelihoods of the population and therefore starts the selection process. Second, to distinguish between different potential partners, negotiations are engaged with the logging companies to design a strategic joint-management plan as the third step. Figure 4 shows the steps of the elaboration of public-private partnerships (PPPs).

\subsection{Multi-Stakeholder Management Approach}

Multi-stakeholder management approach goes beyond the formal and classical PPP scheme in integrating local dwellers in the management process. Introducing local population aims at improving decision-making process during the planning, design, implementation and evaluation phases. In the forest sector to optimize decision-making the process should cover all stakeholders including groups that are marginalized such as women and unemployed youth, the pygmies etc. Moreover, beyond an improvement of decision-making process, an introduction of local stakeholders provides two additional advantages. First, local stakeholders facilitate the control of government decisions applied to logging companies through a social mobilization via cooperatives, social networks and stand-alone control agents-witnesses. This can be done through the support of local district institutions existing at the decentralized level.

Secondly, introducing local dwellers also facilitates capacity building especially for unemployed youth. Indeed when organized around groups, associations, NGOs, local population can request from their public authorities the decision to include social actions in the manner in which the timber is exploited by logging companies. These social actions could be undertaken by logging companies in directly building schools, hospitals and roads in the communities where forest resources are exploited. Logging companies could also be committed—by public authorities-to allocate a certain percentage of their profits to the representatives of the community (internal elites) to contribute to the development of the village. Finally, including local population is important for benefit sharing and an impediment of conflicts. All these issues are very important since the Government does not have the basic information required to impose such social actions to logging companies without considering local populations who know better the interests of their own communities.

\section{Conclusion}

The objective of this paper was to provide an institutional framework stimulating joint management of forest resources in African country of Cameroon. After having summarized the nature and the dynamics of the current institutions in charge of forest management in the country, we have shown how identification and allocation of property rights strengthen forest management. A summary of current property rights used in Cameroon is debated and linkages between property rights and the logging sector of the country are provided. This paper also challenges the constraints impeding the monitoring of policy measures. We argue that controls should be undertaken through a combination of government officials and local populations to build a hybrid form of complementary in which interests of both parties are balanced. We argue that good design and allocation of property rights promote a paradigm shift, requiring new arrangements in which the interests of all stakeholders are included in the decision process. Furthermore we propose two forms of institutional arrangements: public-private 


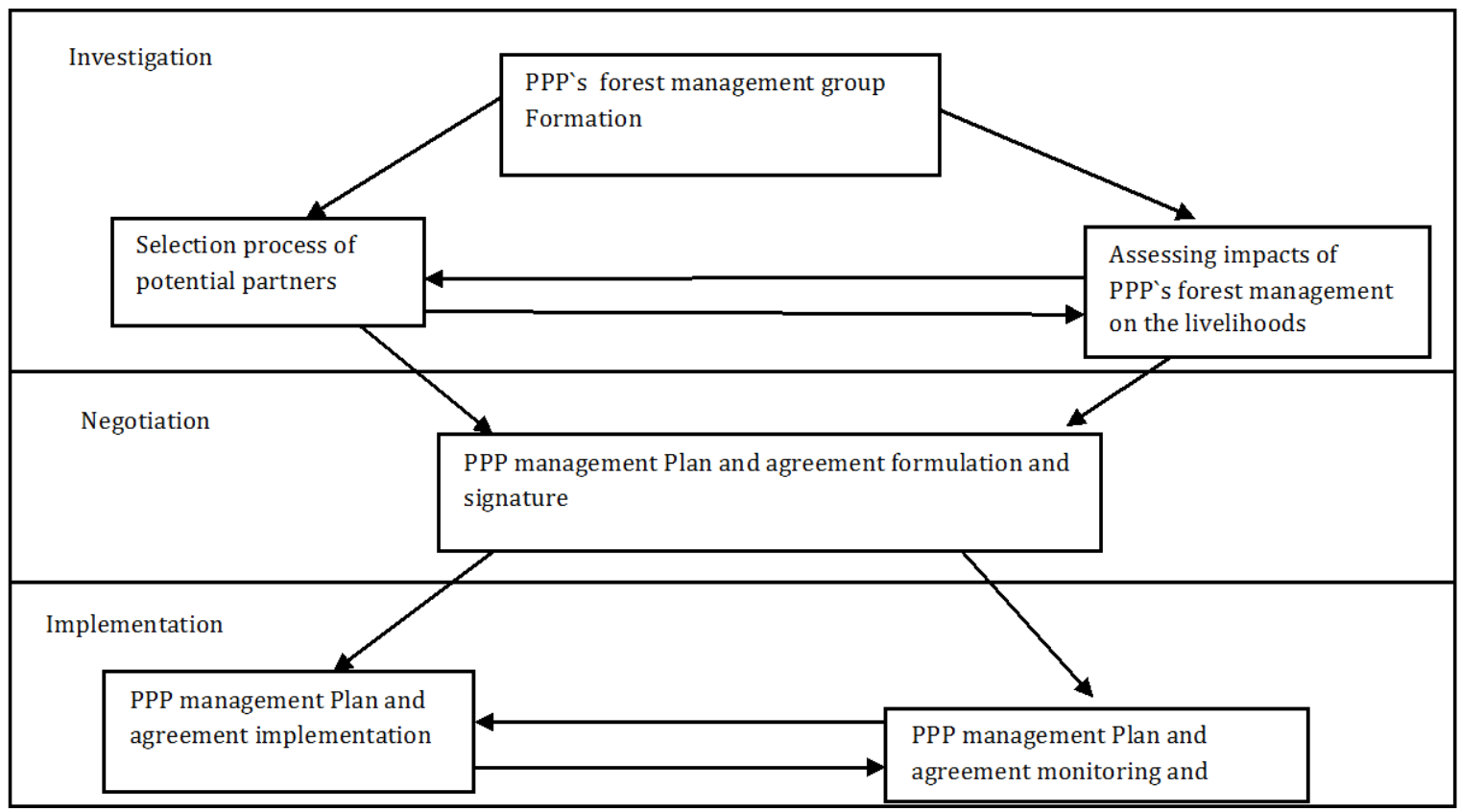

Figure 4. Steps of the elaboration of the public-private partnerships (PPPs).

partnership and multi-stakeholder management approaches. Public-private partnerships are joint project management processes operated by both private businesses and public entities in order to combine public prescriptive mechanisms with private operational roles. Multi-stakeholder management approach is also a co-management approach combining public entities, private actors and local populations in order to increase the weight of local dwellers living in forest areas in the decision process.

\section{Acknowledgements}

The author is grateful for helpful comments provided by Grace Villamor, Sylvie Ferrari and Franz Gatzweiler. The author remains responsible for all remaining errors.

\section{References}

[1] Food and Agriculture Organization of the United Nations (FAO) (2002) Status and Trends in Forest Management in Central Afri Canforest Management Working Paper, FM/3. FAO.

[2] Food and Agriculture Organization for the United Nations (FAO) (2005) Forest and Climate Change in Africa: Rising the Challenges. FAO, Mozambique.

[3] Food and Agriculture Organization for the United Nations (FAO) (2006) Global Forest Resources Assessment 2005, Main Report. Progress towards Sustainable Forest Management FAO Forestry Paper 147, Rome.

[4] Geller, S., McConnell, R. and Wanyiri, J. (2007) Linking National Forest Programmes and Poverty Reduction Strategies: Kenya. FAO, Forestry Department, Forest Policy and Institutions Services.

[5] Gilmour, D. and Fisher, B. (2011) Reforming Forest Tenure: Issues, Principles and Process. FAO Forestry Paper 165, Rome.

[6] Heubach, K., Witting, R., Nuppenau, E.-A. and Hahn, K. (2011) The Economic Importance of Non-Timber Forest Products (NTFPs) for Livelihood Maintenance of Rural West African Communities: A Case Study from Northern Benin. Ecological Economics, 70, 1991-2001.

[7] Nkem, J., Fobissie, K.B., Idinoba, M., Somorin, O.A., Ndoye, O. and Awono, A. (2009) Shaping Forest Safety Nets with Markets: Adaptation to Climate Change under Changing Roles of Tropical Forests in Congo Basin. Environmental Science \& Policy, 498-508.

[8] Food and Agriculture Organization of the United Nations (2007) Forests and Energy in Developing Countries, FAO, Forests and Energy Working Papers 2. 
[9] World Bank (WB) (2010) A Legal and Institutional Framework for Sustainable Management of Forest Resources in Southern Sudan: Policy Note. World Bank.

[10] Anderson, K. and Agrawal, A. (2011) Inequalities, Institutions, and Forest Commons. Global Environmental Changes, 21, 866-875.

[11] Nssah, E., James Gockowski, J. and Kelly, L.A. (2000) A New Deal for Cameroon’s Forests? In: Managing a Global Resource Challenges of Forest Conservation and Development (5 ed.), World Bank Series on Evaluation and Development, Uma Lele, 137-165.

[12] Amariei, L. (2005) Legal Compliance in the Forest Sector: A Case Study of Cameroon. Final Report. FAO, Rome.

[13] Food and Agriculture Organization for the United Nations (FAO) (2008) Links between National Forest Programmes and Poverty Reduction Strategies, by R. McConnell. Forestry Policy and Institutions Working Paper No. 22. Rome.

[14] Food and Agriculture Organization for the United Nations (FAO) (2011) Forests for Improved Nutrition and Food Security, Policy Brief.

[15] Heltberg, R. (2000) Property Rights and Natural Resource Management in the Developing Countries. Institute of Economics, University of Copenhagen, Mimeo.

[16] Mehta, L., Leach, M., Newell, P., Scoones, I., Sivarama Krishnan, K. and Way, S.-A. (1999) Exploring Understandings of Institutions and Uncertainties: New Directions in Natural Resource Management. Institute of Development Studies (IDS), UK.

[17] Rafi Khan, S., Pracha, A.S. and Shaheen, N. (2007) The Quest for Sustainable Forest Management: Exploring PublicPrivate Partner Ships in the Forestry Sector in Pakistan. Sustainable Development Policy Institute, FAO.

[18] Ministry of Forest and Wildlife (MINFOF) (2011) Projet de conservation et d'utilisation durable de la foret de Ngoyla-Mintom: Analyse des dynamiques sociales et evaluation des acteurs et deleurs besoins en renforcement des capacities. Yaoundé Cameroon.

[19] Nabli, M.K. and Nugent, J.B. (1989) The New Institutional Economics and Its Applicability to Development. World Development, 17, 1333-1347. http://dx.doi.org/10.1016/0305-750X(89)90076-4

[20] Foahom, B. (2001) Biodiversity Planning Support Programme, Integrating Biodiversity into the Forest Sector: Cameroon Case Study in Integration of Biodiversity in National Forestry Planning Programme. CIFOR, Indonesia.

[21] Ministére de la Forêt et de l’Environnement (MINEF) (2002) Bilan diagnostic de l'état de la biodiversité dans quelques UFA du Sud Cameroon, MINEF, Cameroon.

[22] Kotto-Same, J., Moukam, A., Njomgang, R., Tiki-Manga, T., Tonye, J., Diaw, C., Gockowski, J., Hauser, S., Weise, S., Nwaga, D., Zapfack, L., Palm, C.A., Woomer, P.L., Gillison, A., Bignell, D. and Tondoh, J. (2000) Alternatives to Slash-and-Burn-Summary Report and Synthesis of Phase II in Cameroon (76 p.). ICRAF, Nairobi.

[23] Brunner, J. and Ekoko, F. (2000) Cameroon. In: Seymour, F.J. and Dubash, N.K., Eds., The Right Conditions, World Resource, Institute Washington, DC, 59-77.

[24] Agrawal, A. (2001) Common Property Institutions and Sustainable Governance of Resources, Montreal. World Development, 29, 1649-1672.

[25] Dang, V. (2009) Institutions and Efficiency in Transition Economies, Economics and Finance Working Paper Series, Working Paper n’ 09 32. Brunel University, London.

[26] Oyono, P.R. (2004) The Social and Organisational Roots of Ecological Uncertainties in Cameroon's Forest Management Decentralisation Model. The European Journal of Development Research, 16, 174-191.

[27] Coleman, E.A. and Mwangi. E. (2013) Women’s Participation in Forest Management: A Cross-Country Analysis. Global Environmental Change, 23, 193-205. http://dx.doi.org/10.1016/j.gloenvcha.2012.10.005

[28] Chappin, M.M.H., Vermeulen, W.J.V., Meeus, M.T.H. and Hekkert, M.P. (2009) Enhancing Our Understanding of the Role of Environmental Policy in Environmental Innovation: Adoption Explained by the Accumulation of Policy Instruments and Agent-Based Factors. Environmental Science \& Policy, 12, 934-947.

[29] Oyono, P.R., Kouna, C. and Mala, W. (2005) Benefits of forests in Cameroon. Global Structure, Issues Involving Access and Decision-Making Hiccoughs. Forest Policy and Economics, 7, 357-368. http://dx.doi.org/10.1016/S1389-9341(03)00072-8

[30] Alemagi, D. and Kazak, R.A. (2010) Illegal Logging in Cameroon: Causes and the Path Forward. Forest Policy and Economics, 12, 554-561.

[31] World Bank (2002) Final Draft of the Forest Law Assessment in selected African Countries. World Bank, Washington DC.

[32] Mitchell, A. (2002) Forest Law Assessment in Selected African Countries. World Bank/WWF Alliance, Washington DC and Zurich. http://www.illegallogging.info/uploads/WWFWorldBankForestLawAssessment.pdf 
[33] Pandya, J. (2002) Logging-A Sustainable Future in Cameroon? WWF Forest for Life Program.

[34] Ostrom, E. (1986) An Agenda for the Study of Institutions. Public Choice, 48, 3-25. http://dx.doi.org/10.1007/BF00239556

[35] Williamson, O.E. (2000) The New Institutional Economics: Taking Stock, Looking Ahead. Journal of Economic Literature, 38, 595-613.

[36] Davis, L.E. and North, D.C. (1971) Institutional Change and American Economic Growth. Cambridge University Press, Cambridge. http://dx.doi.org/10.1017/CBO9780511561078

[37] Hall, P.A. and Taylor, R.C.R. (1996) Political Science and the Three New Institutionalisms. Political Studies, 44, 936957.

[38] Thelen, K. (1999) Historical Institutionalism in Comparative Politics. Annual Review of Political Science, 2, 369-404. http://dx.doi.org/10.1146/annurev.polisci.2.1.369

[39] Thelen, K. (2003) How Institutions Evolve: Insights from Comparative Historical Analysis. In: Mahoney, J. and Rueschemeyer, D., Eds., Comparative Historical Analysis in the Social Sciences, Cambridge University Press, Cambridge, 208-240.

[40] Ostrom, E. (1999) Revisiting the Commons: Local Lessons, Global Challenges. Science, 284, 278-282.

[41] Pearce, D.W. and Warford, J.J. (1993) World without End: Economics, Environment and Sustainable Development. Oxford University Press, New York.

[42] Wardell, D.A., Reenberg, A. and Tottrup, C. (2003) Historical Footprints in Contemporary Land Use Systems: Forest Cover Changes in Savannah Woodlands in the Sudano-Sahelian Zone. Global Environmental Change, 13, 235-254. http://dx.doi.org/10.1016/S0959-3780(03)00056-6

[43] Ministére de la Forêt et de l’Environnement (MINEF) (1994) Loi n’ 94/01 du 20 Janvier 1994 portant régime des forêts, de la faune et de la pêche. Republique du Cameroon, Yaoundé.

[44] Namaalwa, J. (2008) When do Property Rights Matter for Sustainable Forest Management? A Case of the UFRIC Sites in Uganda. IFRI Working Paper \# W08I-2, International Forestry Resources and Institutions Program.

[45] Hardin, G. (1968) The Tragedy of the Commons. Science, 162, 1243-1248. http://dx.doi.org/10.1126/science.162.3859.1243

[46] Randall, A. (1975) Property Rights and Social Microeconomics. Natural Resources Journal, 15, 747-759.

[47] Kherallah, M. and Kirsten, J. (2001) The New Institutional Economics: Application for Agricultural Policy Research in Developing Countries. International Food Policy Research Institute (IFPRI), MSSD Discussion Paper No. 41, Washington.

[48] Alden Wily, L. (2008) Custom and Commonage in Africa Rethinking the Orthodoxies. Land Use Policy, 25, 43-52. http://dx.doi.org/10.1016/j.landusepol.2007.02.002

[49] GOC (1974) Ordonnance No. 74-1 du juillet 1974 fixant le regimefoncier. http://www.spm.gov.cm/fr/documentation/textes-legislatifs-et-reglementaires/article/decret-n-2005481-du-16-decembr e-2005-modifiant-et-completant-certaines-dispositions-du-decret-n-7.html

[50] Heltberg, R. (2002) Property Rights and Natural Resource Management in Developing Countries. Journal of Economic Surveys, 2, 189-215.

[51] Schlager, E. and Ostrom, E. (1992) Property Rights Regimes and Natural Resources: A Conceptual Analysis. Land Economics, 68, 249-262.

[52] Bouriaud, L. and Schmithüsen, F.J. (2005) Allocation of Property Rights on Forests through Ownership Reform and Forest Policies in Central and Eastern European Countries. Swiss Forestry Journal, 156, 297-305.

[53] Eba’s Atyi, R. (2009) Study on Development and Progress in Timber Procurement Policies. Country Case Study: Cameroon. International Tropical Timber Organization (ITTO).

[54] Karsenty, A. (2006) Adjudications des concessions, rente économique et risque financier: Le débat sur la fiscalité au Cameroun et en Afrique centrale. Bois et Forêts des Tropiques, 287, 77-83.

[55] Grut, M., Gray, J.A. and Egli, N. (1991) Forest Pricing and Concession Policies: Managing the High Forests of West and Central Africa. World Bank Technical Paper No. 143. World Bank Africa Technical Department, Washington DC. 